\title{
First record of fossil anguines (Squamata; Anguidae) from the Oligocene and Miocene of Turkey
}

\author{
Andrej Čerňanský ${ }^{1}$ Davit Vasilyan ${ }^{2,3}$ - Georgios L. Georgalis ${ }^{3,4} \cdot$ Peter Joniak $^{5}$ • \\ Serdar Mayda ${ }^{6} \cdot$ Jozef Klembara $^{1}$
}

\begin{abstract}
Fossil anguine lizard specimens from several Turkish localities are described in this paper. The material comes from ten different localities, spanning a large geographic area consisting of both parts of the European Turkey and Anatolia, and ranging in age from the Oligocene to the Late Miocene. In certain cases, the generic determination was possible and, accordingly, members of Ophisaurus and Anguis were identified and described in detail. The specimens of Anguis, found in different, Middle and Late Miocene localities from Anatolia, represent two of only a few fossil occurrences of this taxon. Moreover, the material reported herein represents the oldest occurrences of anguine lizards, not only from Turkey, but from southeastern Europe and the Eastern Mediterranean basin as a whole. These rare records provide important information about the dispersal routes of anguines from Europe
\end{abstract}

Jozef Klembara

klembara@fns.uniba.sk

1 Department of Ecology, Faculty of Natural Sciences, Comenius University in Bratislava, Mlynská dolina, 84215 Bratislava, Slovakia

2 JURASSICA Museum, Route de Fontenais 21, 2900 Porrentruy, Switzerland

3 Department of Geosciences, University of Fribourg/Freiburg, 1700 Fribourg, Switzerland

4 Dipartimento di Scienze della Terra, Università di Torino, 10125 Turin, Italy

5 Department of Geology and Paleontology, Faculty of Natural Sciences, Comenius University in Bratislava, Mlynská dolina, 84215 Bratislava, Slovakia

6 Department of Biology, Faculty of Science, Ege University, 35100 Bornova, Izmir, Turkey to Asia and significantly enhance our understanding of their biogeography.

Keywords Anguimorpha Cenozoic · Dispersion · Asia

\section{Introduction}

The clade Anguinae (Anguimorpha, Anguidae) comprises legless lizards and includes three extant taxa: Pseudopus (Southeast Europe to Central Asia), Anguis (Europe, Western Asia) and Ophisaurus (North America, Northern Africa and Southeast Asia). On the basis of the fossil finds as well as the mitochondrial DNA of the extant species it is believed that the ancestor of the Anguinae probably originated in North America. From there it would have migrated during the Paleocene and Eocene via the land bridge of Greenland and Spitsbergen from North America to Europe (Klembara 1981; Macey et al. 1999). The earliest unambiguous records of this clade in Europe come from the Eocene of Belgium, France, and Great Britain probably representing the genera Ophisaurus and Anguis (Augé 1990, 2005; Klembara and Green 2010). The oldest known certain record of Pseudopus is from the Early Miocene of Germany (Čerňanský et al. 2015), but it is not possible to exclude its presence already in the Late Oligocene of Germany (Čerňanský et al. 2016).

In Europe, the fossil history of the Anguinae clade is well documented from the Cenozoic era (Klembara and Rummel 2016 and references therein; Georgalis et al. 2016a). Anguis and Pseudopus persist in Europe and Western Asia to the present, but Ophisaurus is now absent from that region and has dispersed during the Cenozoic into North Africa (Blain et al. 2013), East Asia and North America (see discussion in Klembara and Rummel 2016; Vasilyan et al. 2017). One of the crucial geographical areas, as for the eastward dispersal 
of Anguinae, is the region of modern day Turkey. However, except for the boine snake Bavarioboa from the Late Oligocene or possibly the Early Miocene of eastern Turkey (Szyndlar and Hoşgör 2012), no other squamates have been recorded from Oligocene and Miocene deposits in Turkey. As for Anguinae, jaws, vertebrae and osteoderms of Ophisaurus and Pseudopus have been documented only from the Pliocene and Pleistocene of Turkey (Rage and Sen 1976; Venczel and Sen 1994; Zwick and Schleich 1994). Pseudopus was also reported from the Quaternary of Lebanon (Hooijer 1961) and Israel (Bar-Yosef and Tchernov 1966; Maul et al. 2010; Smith et al. 2015).

Here we describe for the first time, material pertaining to anguines from several Cenozoic Turkish localities of different age (Fig. 1), extending from the Oligocene (Kocayarma MP 23-MP 27, MP 25?) to the Late Miocene (Süleymanli, MN 13). Although the material is fragmentary, it provides important information about the evolution of this clade in Anatolia and southeastern Europe, and supports the existence of geographical links between terrestrial squamate faunas between Europe and southwestern Asia from the Oligocene to the Early Miocene.

\section{Materials and methods}

Most fossils described herein are deposited in the Natural History Museum of Ege University in Izmir (Turkey) and are prefixed following the format "EUNMH PV-number".
Other material is stored at the Palaeontological collections of the Faculty of Geosciences, University of Utrecht (The Netherlands) and are prefixed by the following formats: "UU KE number", "UU KAR number", "UU CD number", "UU BAG number", and "UU SLM number". Photographs were taken with a Leica DVM5000 at the University of Tübingen, Germany and a Leica M205 C binocular microscope with axially mounted DFC $290 \mathrm{HD}$ camera, LAS software (Leica Application Suite) version 4.1.0 (build 1264) at the Comenius University in Bratislava, Slovakia, and a Leica M205 microscope and the Leica application suite V 3.3.0 at the University of Torino, Italy. The dentary KAR 1102 was also photographed with scanning electron microscope (SEM-FEI XL30 Sirion FEG) at University of Fribourg, Switzerland). The image processing program ImageJ (Schneider et al. 2012) was used for measurements.

\section{Geological settings}

The fossil material described in this paper originates from ten different Late Oligocene to Late Miocene localities in Turkey (Table 1). Only the most relevant data concerning the geological settings of these localities are presented below.

Kavakdere and Kocayarma On the basis of micromammals, the age of both these faunas was determined by Ünay (1989) as Oligocene, within the range of MP 23-MP

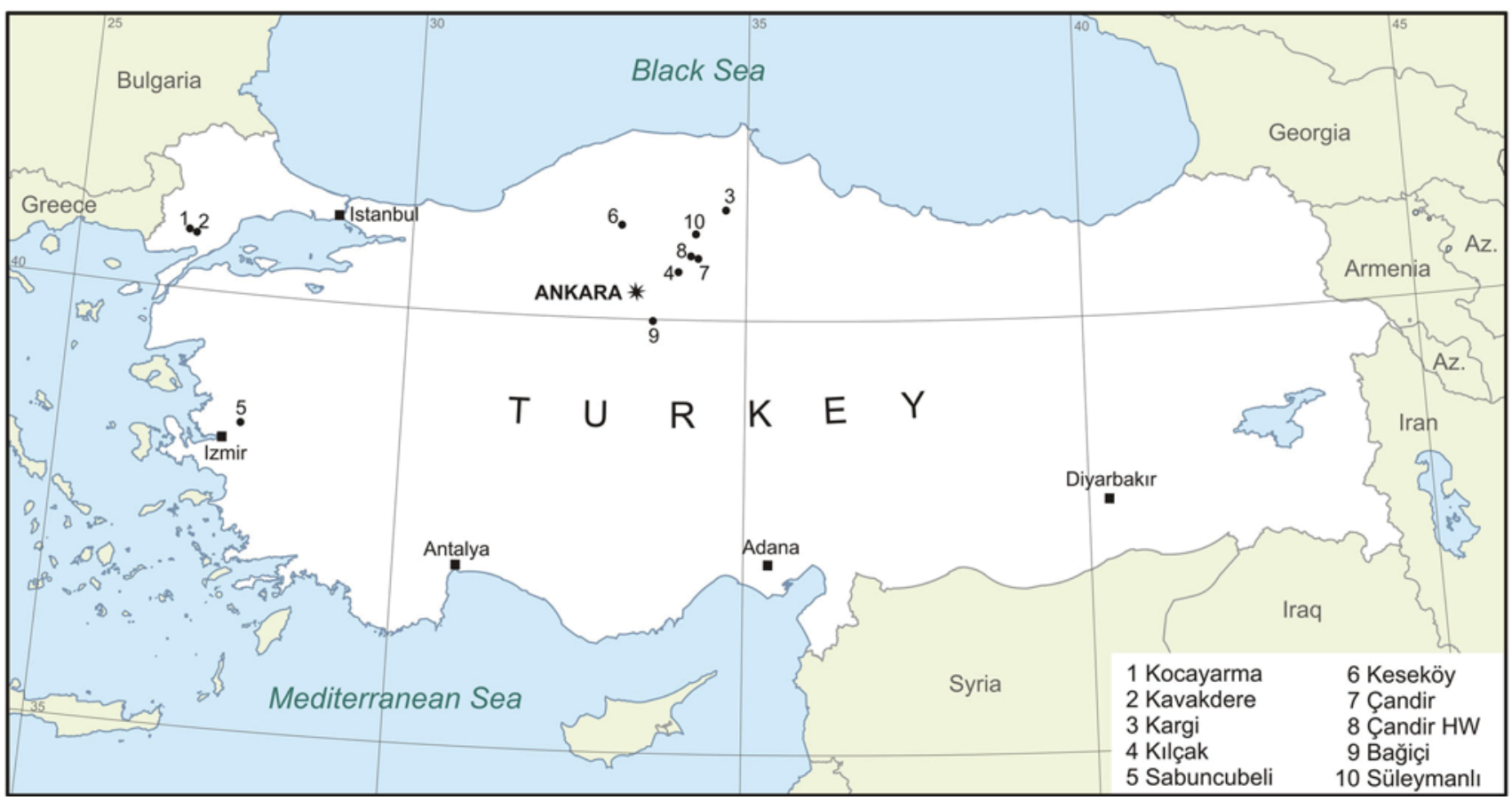

Fig. 1 Map of Turkey with indication of the fossil localities with anguine specimens described herein 
Table 1 List of taxa examined from Turkish Oligocene and Miocene localities

\begin{tabular}{|c|c|c|c|c|}
\hline & Ophisaurus & Anguis & Anguidae indet. & Age \\
\hline Kocayarma & & & + & MP 25 \\
\hline Kavakdere & & & + & MP 26/27 \\
\hline Kargi 2 & + & & + & MP 30-MN 1 \\
\hline Kargi 3 & & & + & MN 1 \\
\hline Kılçak 3b & & & + & MN 1 \\
\hline Sabuncubeli & & & + & MN 3 \\
\hline Keseköy & + & & + & MN 3 \\
\hline Çandir and Çandir HW & + & & + & MN 6 \\
\hline Bağiçi & + & + & + & $\mathrm{MN} 7 / 8$ \\
\hline Süleymanli & + & + & + & MN 13 \\
\hline
\end{tabular}

27, while she considered that the association of two rodents, a rather large-sized Suevosciurus ehingensis and Edirnella, is indicative of MP 25. This age is also consistent with that of radiometric age (33-32.2 Ma) that was sampled from the volcanic tuff overlying the Kavakdere fossiliferous zone (Ünay 1989).

Kargi The section is situated in a coal quarry located near the village of Dodurga. The deposits show a rhythmic alternation of white limestones and dark green clays. Three fossiliferous layers in the mine have been sampled for mammal fossils. The biostratigraphic correlations suggest that Kargi 2 lies at the Oligocene-Miocene transition (local zone A, MP 30-MN 1), and Kargi 3 is of Early Miocene age (local zone B, MN1) (Wessels et al. 2001; van den Hoek Ostende 2001; Ünay et al. 2003; de Bruijn et al. 2013; Kakali 2013).

Kilçak The sections from where fossils were collected are open lignite mines, located near the village of Kılçak. The whole area is completely disturbed and covered by landslides, therefore lithostratigraphic correlation of layers is difficult to be observed. Sediments are mainly grey-green clay, rich in mollusk debris, with several thin lignite horizons. The fossiliferous level Kilçak $3 b$ is one of the layers sampled by a Dutch team during the early 1990s, with the other layers named Kılçak 0, Kılçak 0", and Kılçak $3 \mathrm{a}$. On the basis of rodent assemblages, Kılçak 0 and $0^{\prime \prime}$ are considered to represent the biostratigraphically oldest levels while Kılçak $3 b$ is the youngest (de Bruijn et al. 1993; de Bruijn and von Koenigswald 1994; Sen et al. 1998). There is a general agreement in the attribution of these assemblages to the local biozone B that is correlated to MN 1 (de Bruijn et al. 2013).

Sabuncubeli The fauna has been collected from the lower part of the Soma Formation, outcropped near the road between Izmir and Manisa. The fossiliferous bed consists of a lower part with fine-grained conglomerate lenses and an upper marly part which contains mollusk debris. The age of the micromammal assemblages was interpreted by de Bruijn et al. (2006) as pertaining to the lower part of MN 3 (local zone C/D), being thus slightly older than Keseköy.

Keseköy This locality is a coal quarry near the town of Kizilcahamam. The section predominantly consists of green-brown, partly laminated clays, intercalated with several coal layers. It contains an assemblage of small mammals that is attributed to the local zone D, being correlated to MN 3 (Ünay et al. 2003; de Bruijn et al. 2013).

Çandir and Çandir $H W$ These localities are represented by several fossiliferous horizons of green-grey silty clays and paleosols, located near Çandir. The correlation of the Çandir assemblages to an appropriate $\mathrm{MN}$ zonation is complicated. Çandir was initially biostratigraphically correlated to MN 6 (de Bruijn et al. 1992) and was subsequently reassigned to the MN5 (de Bruijn et al. 2003). As such, the age of Çandir is still under debate and is thus dated either as MN5 or MN6 (Casanovas-Vilar et al. 2011; Mayda et al. 2015). Using both biochronological correlations MN 5 and MN 6, the magnetostratigraphic studies (Krijgsman 2003) correlated Çandir to the base of the chron C5ACn, $14 \mathrm{Ma}$ and $\mathrm{C} 5 \mathrm{ABn}, 13.6 \mathrm{Ma}$ respectively. In any case, the overall faunal resemblance between Paşalar and Çandir allows a confident correlation of Çandir with the local zone F (de Bruijn et al. 2013). The locality Çandir HW represents a test sample from a temporal outcrop near the original locality. The small mammal assemblage of Çandir HW consists of few isolated teeth of the rodents Megacricetodon sp., Democricetodon sp., Cricetodon candirensis, Pliospalax sp., and Spermophilinus bredai. The assemblage cannot be precisely biostratigraphically interpreted, though it suggests the same age as the original Çandir locality, correlating with the local zone F.

Bağiçi This locality has been mostly known in the literature under its former name "Zivra". According to Saraç (1994) the fauna is characterized by its rich and diverse micromammal assemblage. Large mammals have also been reported by Sickenberg et al. (1975). Both small and large 
mammals correspond stratigraphically to the local zone $\mathrm{H}$ (MN 7/8) (Saraç 2003; de Bruijn et al. 2013).

Süleymanli Situated near the village of Süleymanli, this locality consists of brown silty clays, rich in vertebrates and gastropod remains. The fauna is not yet described in detail, however, the age of the assemblage has been determined as Late Miocene (MN 13, local biozone L; see de Bruijn et al. 2013).

\section{Systematic palaeontology}

\author{
Squamata OPPEL, 1811 \\ Anguimorpha FÜRBRINGER, 1900 \\ Anguidae GRAY, 1825 \\ Anguinae GRAY, 1825 \\ Ophisaurus DAUDIN, 1803
}

\subsection{Ophisaurus sp. (Fig. 2a-i)}

Material, locality and horizon Right dentary UU KAR2 1102, Kargi 2, Oligocene/Miocene, MP 30/MN 1; dorsal vertebra UU KAR2 1101, Kargi 2, Oligocene/Miocene, MP 30/MN 1; dorsal vertebra UU KE 5101, Keseköy, Lower Miocene, MN 3; dorsal vertebra UU CD 5101, Çandir, Middle Miocene MN 6; dorsal vertebra UU BAG 5104, Bağiçi, late Middle Miocene, MN 7/8; dorsal vertebra EUNMH PV-14000, Süleymanli, Upper Miocene, MN 13.

\subsubsection{Description}

Right dentary Specimen UU KAR 1102 represents a small fragment of the right dentary, preserving two tooth positions (Fig. 2a). Only one tooth is almost complete, with its apex, however, being damaged. The second, more anteriorly located tooth is broken off, preserving only its base. The subdental shelf (sensu Rage and Augé 2010) is thin. The preserved portion of the shelf has a straight course. Meckel's groove is fully open.

Dentition The dentition is pleurodont, with teeth being large and conical. They are pointed and only slightly curved posteriorly. The mesial and distal cutting edges are well developed in the apical section of the tooth height. The medial surface of the apex bears very faint striae which continue through the surface of the cutting edge.

Dorsal vertebrae The description of the dorsal vertebrae is based mainly on the best preserved specimen, UU KE 5101, from Keseköy (Fig. 2b-f). The vertebra is markedly anteroposteriorly elongated relative to its height. In anterior view, the vertebra is approximately 1.5 times wider than high. The median ridge is gradually ascending posteriorly, forming a dorsally elevated neural spine in the posterior-most section. Unfortunately, the dorsal portion of
4 Fig. 2 Ophisaurus sp. Right dentary from Kargi 2 (UU KAR2 1102) in a medial aspect; vertebrae from b to f Keseköy (UU KE 5101), g, h Kargi 2 (UU KAR2 1101) and i Süleymanli (EUNMH PV-14000), in $\mathbf{b}$ dorsal; c, $\mathbf{g}$, $\mathbf{i}$ ventral; $\mathbf{d}, \mathbf{h}$ lateral, $\mathbf{e}$ anterior and $\mathbf{f}$ posterior aspects

the neural spine is broken off in the Keseköy specimen. In dorsal view, the ridge is thin and sharp, well defined along its entire length. It rather slightly widens posteriorly. The posterior-most section is distinctly wider than the anterior rest of the median ridge (in UU KAR2 1101, the neural spine forms a dorsally high structure, rectangular in lateral aspect, posteriorly inclined, ovoid in cross section, but frustratingly, its dorsal tip and the anterior portion are broken). The neural canal is moderately sized and roughly pentagonal in shape. The pre- and postzygapophyses are well expanded laterally. A strong interzygapophyseal constriction is developed between them, forming a deep lateral notch on both sides in dorsal view. The prezygapophyses bear roughly square articulation surfaces. They are inclined from the horizontal plane in an angle of approximately $36^{\circ}$. The synapophyses are rectangular in shape. The cotyle is not completely preserved in UU KE 5101, but it is well preserved in UU KAR2 1101 (Fig. 2g, h). In all specimens, the cotyle is strongly depressed and its height is slightly larger than the height of the neural canal. The condyle is elliptical and also depressed. The ventral surface of the centrum is flat. In UU KE 5101, the ventral surface of the centrum is partially damaged. However, this portion is well preserved in EUNMH PV-14000 or UU KAR2 1101. In EUNMH PV-14000 (Fig. 2i), the ventral surface of vertebra possesses two asymmetrically located subcentral foramina. In this specimen, almost parallel edges, limiting the flat ventral portion of the centrum, run from the lateral limits of the cotyle posteriorly to the condyle, and appear to be sharper and more strongly developed than those in the Keseköy and Kargi 2 specimens. The lateral margins (subcentral ridges) of the centrum are concave and the centrum gradually narrows posteriorly.

\subsubsection{Remarks}

Among extant anguine genera, the tooth morphology of UU KAR 1102 resembles that of Ophisaurus, specifically $O$. koellikeri, O. harti, O. ventralis and O. attenuatus. However, in all these extant species the striations are much more distinctly developed (Klembara et al. 2014). Only in small specimens of Ophisaurus, the striae on the apices of teeth are very faint (e.g., O. acuminatus; Klembara et al. 2014: Fig. 13E-G). According to its size, UU KAR2 1102 specimen corresponds to adult specimens of extant Ophisaurus (e.g., O. koellikeri). However, the morphology of 


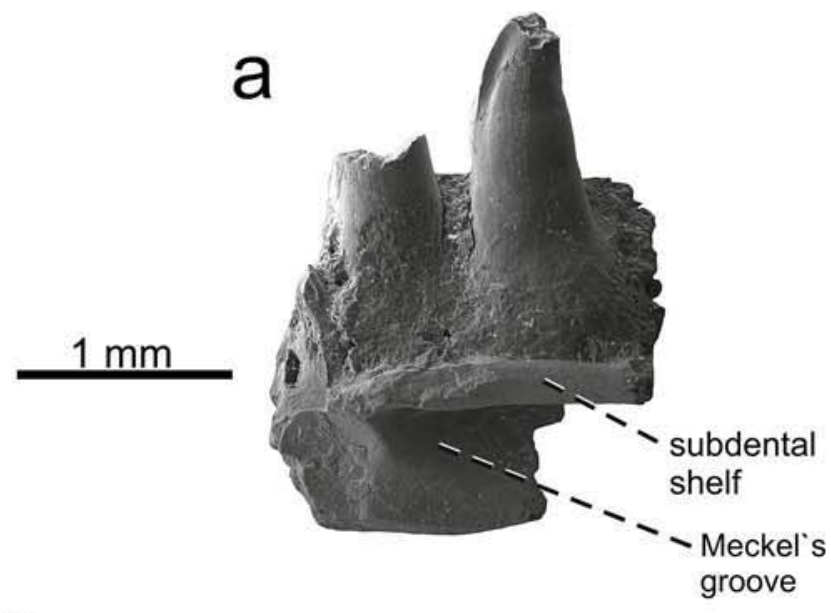

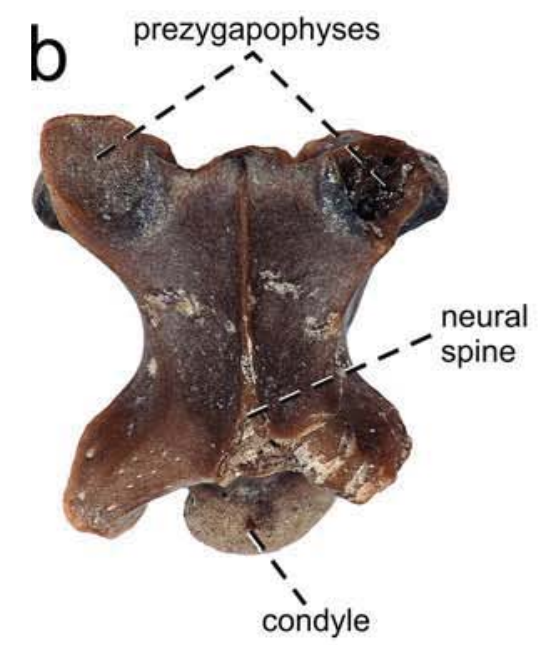

C
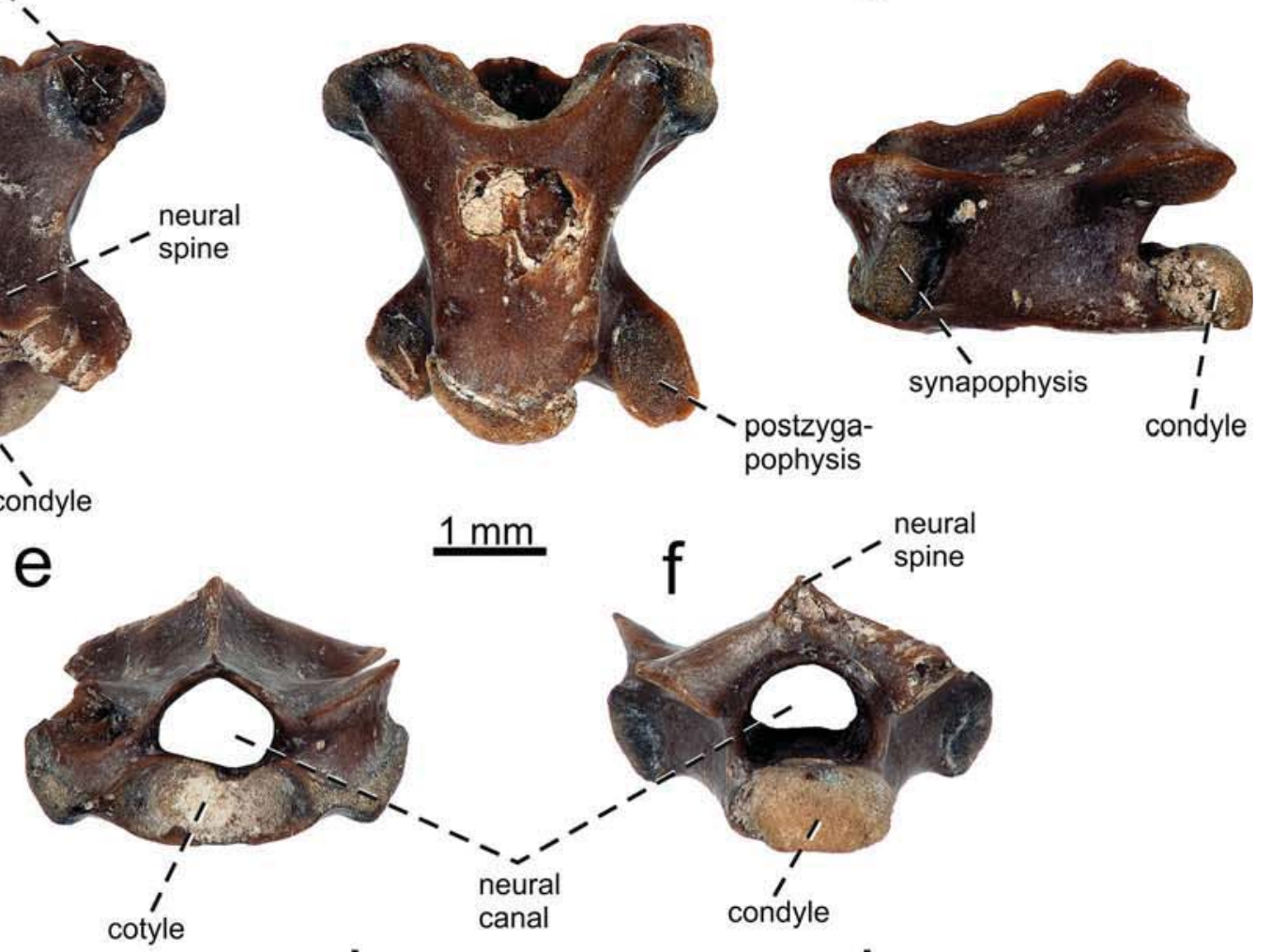

g

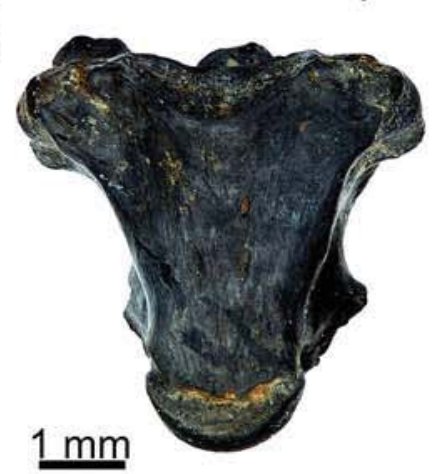

h

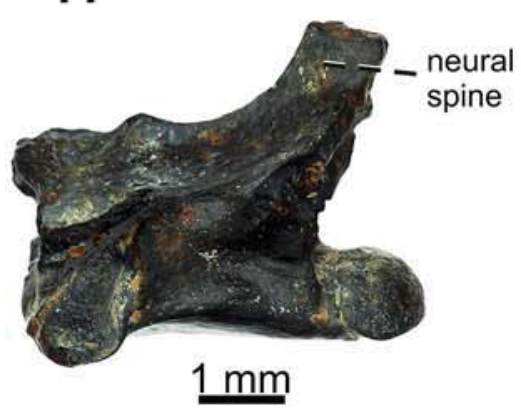

d

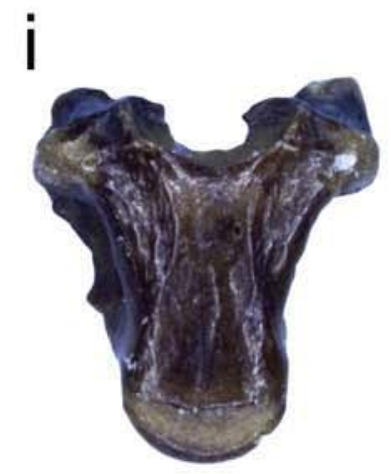

$1 \mathrm{~mm}$ 
the tooth of UU KAR2 1102 specimen is very similar to the one recently described from the late Middle Miocene of Kazakhstan (Vasilyan et al. 2017).

A morphology of the teeth similar to that of UU KAR 1102 is also present in Ophisauromimus from the European Oligocene (Čerňanský et al. 2016). However, in well preserved teeth of Ophisauromimus, it is clearly visible that the cutting edges of the teeth are much longer in comparison to the length of the tooth and the cutting edges extend to the tooth base (Čerňanský et al. 2016: Fig. 14G, G1).

The concave lateral walls of the centrum of the dorsal vertebrae allow their taxonomic assignment to Ophisaurus. In contrast, straight lateral walls on the centrum are present in the dorsal vertebrae of adult specimens of Pseudopus (Klembara 1981: Fig. 3). Additionally, in Pseudopus the cotyle is significantly dorsoventrally higher than the height of the neural canal (see Čerňanský et al. 2016).

Anguis LINNAEUS, 1758.

\subsection{Anguis sp. (Fig. 3)}

Material, locality and horizon Dorsal vertebra UU BAG 5101, Bağiçi, late Middle Miocene, MN 7/8; dorsal vertebra EUNMH PV-14001, Süleymanli, Upper Miocene, MN 13.

\subsubsection{Description}

Dorsal vertebra The description is based on the well preserved specimen UU BAG 5101 (Fig. 3a-e). The vertebral centrum is anteroposteriorly elongated. The height of the vertebra slightly gradually increases posteriorly. The neural spine is markedly low. It forms a ridge running along almost the entire length of the dorsal section of the neural arch. In dorsal aspect, the ridge is thin, becoming less distinct in the anterior section. In the posterior two thirds of its length, it is well defined and widens at its posterior end.
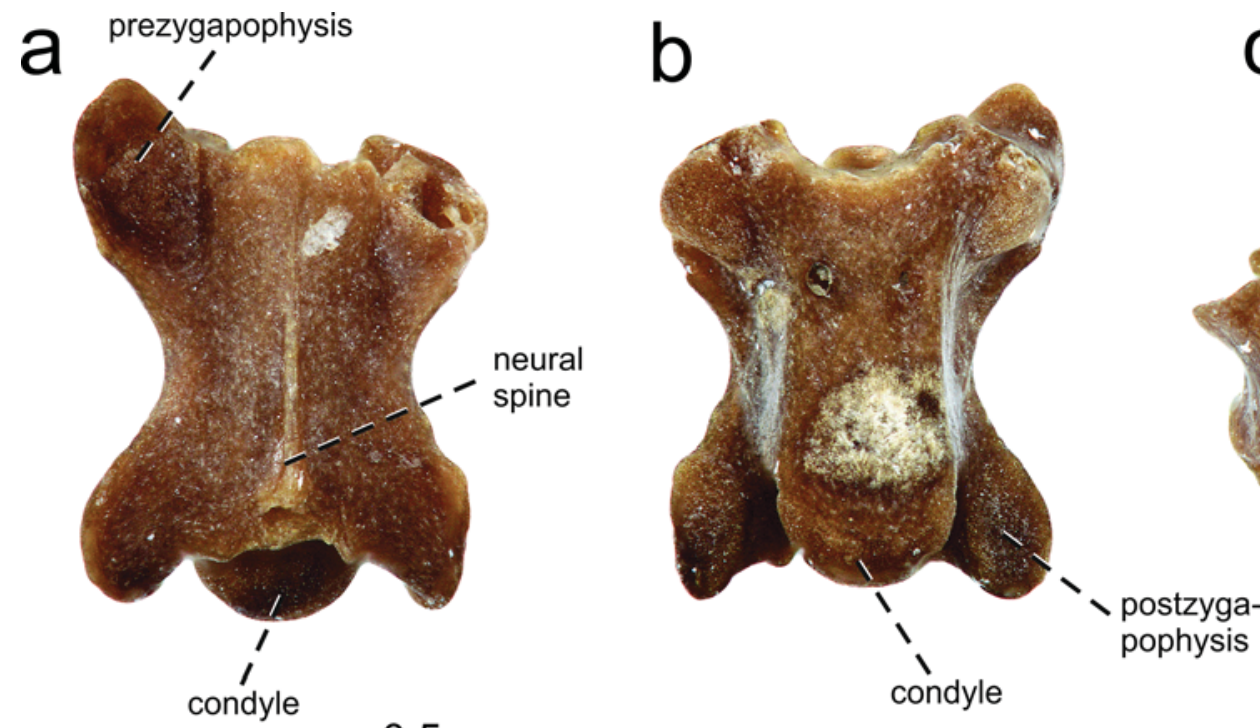

C
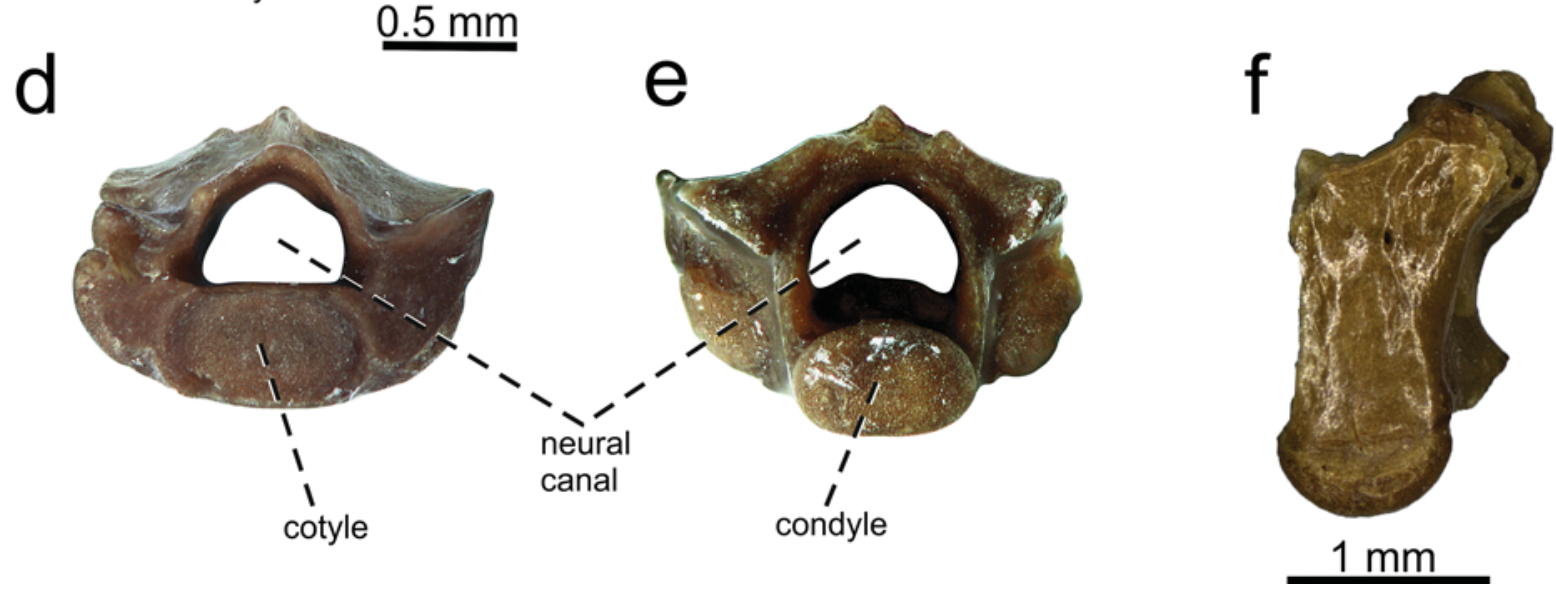

Fig. 3 Anguis sp. Vertebrae from a to e Bağiçi (UU BAG 5101) and f Süleymanli (EUNMH PV-14001), in a dorsal; b, f ventral; c lateral; d anterior; and e posterior aspects 
The neural canal is large and roughly triangular in shape. The pre- and postzygapophyses are well expanded laterally, bearing elliptical articulation surfaces. A well developed interzygapophyseal constriction is located between them. The prezygapophyses are inclined from the horizontal plane in an angle of approximately $45^{\circ}$. The synapophyses are square in shape. The cotyle is large and its height is slightly bigger that the height of the neural canal (Fig. 3d), a typical diagnostic feature of Anguis and Pseudopus. The cotyle is depressed, as well as the condyle, which is markedly protruded posteriorly. The ventral surface of the centrum is flat, possessing two subcentral foramina in the anterior one third of the centrum. The lateral margins of the centrum run almost parallel, but the centrum is constricted at the level of the subcentral foramina.

\subsubsection{Remarks}

These vertebrae can be attributed to Anguis based on the course of the lateral margin of the vertebral centrum in ventral aspect. In extant Anguis, the lateral margins are almost parallel in ventral view, with a slight constriction immediately posterior to the subcentral foramina (Klembara 1981, Fig. 3).

\subsection{Anguinae indet. (Fig. 4)}

Material, locality and horizon Caudal vertebra UU KE 5102, Keseköy, Lower Miocene, MN3; osteoderm EUNMH PV-14003 Kocayarma, Oligocene MP 23-MP 27 or ? MP 25; osteoderm EUNMH PV-14021, Kavakdere, Oligocene MP 26/27; osteoderm EUNMH PV-14021, Kılçak 3b, Lower Miocene, MN 1; osteoderm EUNMH PV-14004, Sabuncubeli, Lower Miocene, MN 3; osteoderm UU KE 5103, Keseköy, Lower Miocene, MN 3; osteoderm UU KAR2 1103, Kargi 2, Oligocene/Miocene, MP 30/MN 1; osteoderms UU KAR3 1101 and UU KAR3 1102, Kargi 3, Lower Miocene, MN 1; osteoderms UU CD 5102, 5103, and 5104, Çandir, Middle Miocene, MN 6; osteoderm EUNMH PV-14005-12, Çandir HW, Middle Miocene, MN 6; osteoderms UU BAG 5102 and 5103, Bağiçi, late Middle Miocene, MN 7/8; osteoderm EUNMH PV-14013-20, Süleymanli, Upper Miocene, MN 13.

\subsubsection{Description}

Caudal vertebra The caudal vertebra (KE 5102) is narrow, anteroposteriorly elongated and roughly cylindrical (Fig. 4a-d). The postzygapophysis is small, posteriorly directed. Only the right one is preserved. The neural canal is large, pentagonal in shape. In lateral aspect, the condyle protrudes well posteriorly. In posterior view, it is markedly depressed. The haemapophyses are fused to the centrum, occupying its posterior region, right anterior to the condyle. Only the bases of the haemapophyses are preserved. The anterolaterally oriented transverse processes are robust, but most of their length is broken. The neural spine and the entire posterodorsal region of the vertebra are broken.

Osteoderms The osteoderms are of several morphotypes. The first morphotype is represented by slender, rectangular osteoderms, with a low medial ridge running along their entire central regions, or sometimes being restricted to the sculpture region (e.g. EUNMH PV-14003, Fig. 4e). In some osteoderms of the same morphotype, the medial ridge runs obliquely (this reflects a body location) (EUNMH PV14013, Fig. 4j). The anterior overlap surface occupies almost one third of the external surface, and the lateral bevel is highest close to the overlap surface. The posterior portion of the external surface is ornamented. The ornamentation is formed by short grooves, tubercles, pits and ridges diverging from the central region. The central part of the internal surface is pierced by three foramina. Shallow grooves are located on the periphery of the internal surface.

Osteoderms of the second morphotype are roughly square in shape and possess no medial ridge (Fig. 4k). In several osteoderms, the lateral bevel is present on both sides.

The third morphotype consists of irregular, or roughly rhomboidal-shaped osteoderms (Fig. 41). The medial ridge is absent.

\section{Discussion}

The specimens of Ophisaurus and Anguis described herein represent the first unambiguous evidence that anguines used the region of Anatolia as a passage on their dispersal route from Europe to East Asia. Although there is only one small fragment of dentary with only one tooth in our material, the morphology of this tooth is extremely similar with that of Ophisaurus sp. described recently from the Middle Miocene of Kazakhstan (Vasilyan et al. 2017).

The material from the localities of Kocayarma (Oligocene, MP 23-MP 27 or ? MP 25) and Kavakdere (MP 26/27) represents the oldest known occurrences of anguid lizards not only from Turkey, but from the whole southeastern Europe. The presence of anguines in the Oligocene of Turkey is consistent with the closing of the Turgai Strait and the establishment of the terrestrial connection between Europe and Asia that opened a dispersal corridor for landdwelling animals (Haq et al. 1987; Rögl 1999). Many lizard lineages appeared in Asia during the Oligocene, among them e.g. lacertids (Böhme 2007), whereas several Asian newcomers appeared for the first time in Europe (Rage 2013). The anguine material described from these 
two Oligocene localities of European Turkey consists only of isolated osteoderms, so its determination to the alpha taxonomy level is currently impossible. Nevertheless, they resemble osteoderms of Ophisaurus, but other taxa cannot be excluded (osteoderms of Ophisauromimus are unknown; Čerňanský et al. 2016). Osteoderms similar to that from Kocayarma (although with a less pronounced sculpturing pattern) have also been described from the European Oligocene, e.g. from Germany (see Čerňanský et al. 2016). In the locality of Kargi 2 (Oligocene/Miocene, MP 30/MN 1), the allocation of the material to Ophisaurus is without any doubt. Based on this fossil record, Ophisaurus appeared in the Asiatic part of Turkey during the terminal Oligocene (and perhaps even slightly earlier). The Oligocene and Miocene rhinocerotoids and associated faunas from several Turkish localities (Antoine et al. 2008; Sen et al. 2011), including the snake Bavarioboa (Szyndlar and Hoşgör 2012), indicate that Anatolia had close terrestrial connections with both Asia and Europe during the late Oligocene and Early Miocene. Therefore, the anguine material described herein from the Asiatic part of Turkey brings additional evidence for links between the terrestrial faunas of Europe and southwestern Asia.

In contrast to Ophisaurus, Anguis and Pseudopus still inhabit Turkey; see e.g. Baran et al. 1988). Pseudopus was not found in our collection of anguines from the available Turkish localities, so very little can be said about its first appearance in the region. Moreover, Anguis seems to have appeared much later in this region, as the oldest fossil record is herein shown to occur in the terminal Middle Miocene (Bağiçi). An hypothetical explanation for this might be the possible absence of suitable environments preferred by this taxon in Turkey (or along its dispersal route) till the end of the Middle Miocene. Members of Anguis are restricted to temperate and humid habitats, such as woodlands, grassland and heathland. Usually Anguis spp. live up to 1000-1500 m above sea level, and avoid open, unshielded areas (see e.g., Gvoždík and Moravec 2015). However, it is worth noting that the fossil finds of Anguis are in general extremely rare (see Klembara and Rummel 2016) so an earlier date of dispersal cannot be fully excluded.

Moreover, the Turkish area is at the crossing of Eurasia and Africa; Northern Africa is part of the Palearctic region as is Eurasia. It should be noted that in Northern Africa, the oldest known anguid lizards are found in the Middle Miocene of Beni Mellal (Morocco; see Rage 1976). Ophisaurus probably migrated to North Africa during the Miocene, as supported by material from the Late Miocene deposits of Morocco (Blain et al. 2013). According to Blain et al. (2013), Ophisaurus may have entered North Africa during or prior to the Middle Miocene via the land bridge between the Afro-Arabian Plate and Eurasia established from the Early Miocene onwards, following a route that is the opposite from the direction of other squamate clades, such as chamaeleonids and cordylids (Čerňanský 2010, 2012; Georgalis et al. 2016b).

\section{Conclusion}

Fossil anguine lizard finds from several Turkish Oligocene and Miocene localities are described here for the first time. These rare records consist of dentary fragment, vertebrae and osteoderms. These skeletal and integumentary elements provide important information about the dispersal routes of anguines from Europe to Asia. The Kocayarma material represents the oldest occurrences of anguine lizards not only from Turkey, but also from the southeastern Europe and the Eastern Mediterranean Basin. The fossils show that Ophisaurus appeared in the Asiatic part of Turkey during the Late Oligocene (and perhaps even slightly earlier), whereas the first appearance of Anguis seems to have happened much later in this region, in the late Middle Miocene.

\section{References}

Antoine, P. O., Karadenizli, L., Saraç, G., \& Sen, S. (2008). A giant rhinocerotoid (Mammalia, Perissodactyla) from the Late Oligocene of north-central Anatolia (Turkey). Zoological Journal of the Linnean Society, 152, 581-592.

Augé, M. (1990). La faune de lézards et d'amphisbaenes (Reptilia Squamata) du gisement de Dormaal (Belgique, Eocène inférieur). Bulletin de l'Institut Royal des Sciences Naturelles de Belgique, 60, 161-173.

Augé, M. (2005). Évolution des lézards du Paléogène en Europe. Mémoires du Muséum national d'Histoire naturelle, 192, 1-369.

Baran, I., Kasparek, M., \& Öz, M. (1988). On the distribution of the Slow Worm, Anguis fragilis, and the European Glass Lizard, Ophisaurus apodus, in Turkey. Zoology in the Middle East, 2, 57-62.

Bar-Yosef, O., \& Tchernov, E. (1966). Archaeological finds and the fossil faunas of the Natufian and Microlithic industries at Hayonim cave (western Galilee, Israel). Israel Journal of Zoology, 15, 104-140.

Blain, H. A., Augustí, J., López-García, J. M., Haddoumi, H., Aouraghe, H., El Hammouti, K., et al. (2013). Amphibians and squamate reptiles from the late Miocene (Vallesian) of eastern Morocco (Guefaït-1, Jerada Province). Journal of Vertebrate Paleontology, 33, 804-816.

Böhme, M. (2007). 3. Herpetofauna (Anura, Squamata) and palaeoclimatic implications: preliminary results. In G. Daxner-Höck (Ed.), Oligocene-Miocene vertebrates from the valley of lakes (Central Mongolia): Morphology, phylogenetic and stratigraphic implications. Annalen des Naturhistorischen Museums in Wien (Vol. 108, pp. 43-52). Vienna: Naturhistorisches Museum Wien.

Casanovas-Vilar, I., Alba, D. M., Garcés, M., Robles, J. M., \& MoyàSolà, S. (2011). Updated chronology for the Miocene hominoid radiation in Western Eurasia. Proceedings of the National Academy of Sciences, 108, 5554-5559. 
Čerňanský, A. (2010). A revision of chamaeleonids from the Lower Miocene of the Czech Republic with description of a new species of Chamaeleo (Squamata, Chamaeleonidae). Geobios, $43,605-613$.

Čerňanský, A. (2012). The oldest known European Neogene girdled lizard fauna (Squamata, Cordylidae), with comments on early Miocene immigration of African taxa. Geodiversitas, 34, 837-847.

Čerňanský, A., Klembara, J., \& Müller, J. (2016). The new rare record of the late Oligocene lizards and amphisbaenians from Germany and its impact on our knowledge of the European terminal Palaeogene. Palaeobiodiversity and Palaeoenvironments, 96, $559-587$.

Čerňanský, A., Rage, J. C., \& Klembara, J. (2015). The early Miocene squamates of Amöneburg (Germany): The first stages of modern squamates in Europe. Journal of Systematic Palaeontology, 13, $97-128$.

de Bruijn, H., Daams, R., Daxner-Höck, G., Fahbusch, V., Ginsburg, L., Mein, P., et al. (1992). Report of the RCMNS working group on fossil mammals, Reisensburg 1990. Newsletters of Stratigraphy, 26, 65-118.

de Bruijn, H., Fahlbush, V., Saraç, G., \& Ünay, E. (1993). Early Miocene rodent faunas from the eastern Mediterranean area. Part III The genera Deperetomys and Cricetodon with a discussion of the evolutionary history of the Cricetodontini. Proceedings van de Koninklijke Nederlandse Akademie van Wetenschappen, Series B, 96, 151-216.

de Bruijn, H., Mayda, S., Van den Hoek Ostende, L. W., Kaya, T., \& Saraç, G. (2006). Small mammals from the Early Miocene of Sabuncubeli (Manisa, SW Anatolia, Turkey). Beiträge zur Paläontologie, 30, 57-87.

de Bruijn, H., Ünay, E., \& Hordijk, K. (2013). A review of the Neogene succession of the Muridae and Dipodidae from Anatolia with special reference to taxa known from Asia and/ or Europe. In L. Wang, J. Flynn, \& M. Fortelius (Eds.), Fossil mammals of Asia: Neogene biostratigraphy and chronology (pp. 564-580). New York: Columbia University Press.

de Bruijn, H., \& von Koenigswald, W. (1994). Early Miocene rodent faunas from eastern Mediterranean area. Part V. The genus Enginia (Muroidea) with a discussion of the structure of the incisor enamel. Proceedings van de Koninklijke Nederlandse Akademie van Wetenschappen, Series B, 97, 381-405.

de Bruijn, H., et al. (2003). Rodents, lagomorphs and insectivores from the Middle Miocene hominoid locality of Çandir (Turkey). Courier Forschunginstitut Senckenberg, 240, 51-87.

Georgalis, G. L., Villa, A., \& Delfino, M. (2016a). Fossil lizards and snakes from Ano Metochi-A diverse squamate fauna from the latest Miocene of northern Greece. Historical Biology. doi:10. 1080/08912963.2016.1234619.

Georgalis, G. L., Villa, A., \& Delfino, M. (2016b). First description of a fossil chamaeleonid from Greece and its relevance for the European biogeographic history of the group. Science of Nature, 103, 12. doi:10.1007/s00114-016-1336-5.

Gvoždík, V., \& Moravec, J. (2015). Anguis fragilis Linneaus, 1758slepýš křehký. In J. Moravec (Ed.), Fauna of the Czech Republic, Reptiles-Reptilia (pp. 398-426). Praha, Academia [in Czech with English summary].

Haq, B., Hardenbol, J., \& Vail, P. (1987). The chronology of fluctuating sea levels since the Triassic. Science, 235, 156-1166.

Hooijer, D. (1961). The fossil vertebrates of Ksar Akil, a Paleolithic rockshelter in Lebanon. ZoologischeVerhandelingen, 49, 4-65.

Kakali, N. (2013). The Early Miocene rodent faunas of Kargi, Anatolia, and their biostratigraphic implications. Master thesis, Universiteit Utrecht, Faculty of Geosciences.

Klembara, J. (1981). Beitragzur Kenntniss der Subfamilie Anguinae. Acta Universitatis Carolinae, Geologica, 2, 121-168.
Klembara, J., \& Green, B. (2010). Anguimorph lizards (Squamata, Anguimorpha) from the Middle and Upper Eocene of the Hampshire Basin of Southern England. Journal of Systematic Palaeontology, 8, 97-129.

Klembara, J., Hain, M., \& Dobiašová, K. (2014). Comparative anatomy of the lower jaw and dentition of Pseudopus apodus and the interrelationships of species of subfamily Anguinae (Anguimorpha, Anguidae). The Anatomical Record, 297, 516-544.

Klembara, J., \& Rummel, M. (2016). New material of Ophisaurus, Anguis and Pseudopus (Squamata, Anguidae, Anguinae) from the Miocene of the Czech Republic and Germany and systematic revision and palaeobiogeography of the Cenozoic Anguinae. Geological Magazine. doi:10.1017/S0016756816000753.

Krijgsman, W. (2003). Magnetostratigraphic dating of the Çandir fossil locality (Middle Miocene, Turkey). Courier Forschunginstitut Senckenberg, 240, 41-49.

Macey, J. R., Schulte, J. A., II, Larson, A., Tunyiev, B. S., Orlov, N., \& Papenfuss, T. J. (1999). Molecular phylogenetics, tRNA evolution, and historical biogeography in anguid lizards and related taxonomic families. Molecular Phylogenetics and Evolution, 12, 250-272.

Maul, L. C., Smith, K. T., Barkai, R., Barash, A., Karkanas, P., Shahack-Gross, R., et al. (2010). Microfaunal remains at Middle Pleistocene Qesem Cave, Israel: Preliminary results on small vertebrates, environment and biostratigraphy. Journal of Human Evolution. doi:10.1016/j.jhevol.2010.03.015.

Mayda, S., Koufos, G. D., Kaya, T., \& Gul, A. (2015). New carnivore material from the Middle Miocene of Turkey. Implications on biochronology and palaeoecology. Geobios, 48, 9-23.

Rage, J.-C. (1976). Les squamates du Miocéne de Beni Mellal, Maroc. Géologie méditerranéenne, 3, 57-70.

Rage, J.-C. (2013). Mesozoic and Cenozoic squamates of Europe. Palaeobiodiversity and Palaeoenvironments, 93, 517-534.

Rage, J.-C., \& Augé, M. (2010). Squamate reptiles from the middle Eocene of Lissieu (France) A landmark in the middle Eocene of Europe. Geobios, 43, 253-268.

Rage, J.-C., \& Sen, S. (1976). Les amphibiens et les reptiles du Pliocène supérieur de Çalta (Turquie). Géologie méditerranéenne, 3, 127-134.

Rögl, F. (1999). Mediterranean and Paratethys. Fact and hypotheses of an Oligocene to Miocene Paleogeography (short overview). Geologica Carpathica, 50, 339-349.

Saraç, G. (1994). Ankara Yöresindeki Karasal Neojen Çökellerinin Rhinocerotidae (Mammalia-Perissodactyla) Biyostratigrafisive Paleontolojisi. PhD disseration, Ankara Üniversitesi Fen Bilimleri Enstitüsü, Ankara.

Saraç, G. (2003). Türkiye Omurgali fosil yataklari. MTA Report No 10609 (unpublished).

Schneider, C. A., Rasband, W. S., \& Eliceiri, K. W. (2012). NIH Image to ImageJ: 25 years of image analysis. Nature Methods, 9 , 671-675.

Sen, S., Antoine, P. O., Varol, B., Ayyildiz, T., \& Sözeri, K. (2011). Giant rhinoceros Paraceratherium and other vertebrates from Oligocene and middle Miocene deposits of the Kağizman-Tuzluca Basin, Eastern Turkey. Naturwissenschaften, 98, 407-423.

Sen, S., Seyitoğlu, G., \& Karadenizli, L. (1998). Mammalian biochronology of Neogene deposits and its correlation with the lithostratigraphy in the Cankiri-Corum Basin, central Anatolia, Turkey. Eclogae Geologicae Helvetiae, 91, 307-320.

Sickenberg, O., Becker-Platen, J. D., Benda, L., Berg, D., Engesser, B., Gaziry, W., et al. (1975). Die Gliederung des höheren Jungtertiars und Altquartarsin der Turkei nach vertebraten und ihre Bedeutung für die Internationale Neogene-Stratigraphie. Geologische Jahrbuch, B15, 1-167.

Smith, K. T., Maul, L. C., Flemming, F., Barkai, R., \& Gopher, A. (2015). The microvertebrates of Qesem Cave: A comparison of 
the two concentrations. Quaternary International. doi:10.1016/j. quaint.2015.04.047.

Szyndlar, Z., \& Hoşgör, I. (2012). Boine snake Bavarioboa from the Oligocene/Miocene of eastern Turkey with comments on connections between European and Asiatic snake faunas. Acta Palaeontologica Polonica, 57, 667-671.

Ünay, E. (1989). Rodents from the Middle Oligocene of Turkish Thrace. Utrecht Micropaleontological Bulletins, Special Publication, 5, 1-120.

Ünay, E., de Bruijn, H., \& Saraç, G. (2003). A preliminary zonation of the continental Neogene of Anatolia based on rodents. Deinsea, 10, 539-548.

van den Hoek Ostende, L. W. (2001). Insectivore faunas from the Lower Miocene of Anatolia. Part 7: The Kargi assemblages. Scripta Geologica, 122, 83-99.
Vasilyan, D., Böhme, M., \& Klembara, J. (2017). First record of fossil Ophisaurus (Anguimorpha, Anguidae) from Asia. Journal of Vertebrate Paleontology. 36(6), e1219739. doi:10.1080/ 02724634.2016 .1219739$.

Venczel, M., \& Sen, S. (1994). Pleistocene amphibians and reptiles from Emirkaya-2, Turkey. Herpetological Journal, 4, 159-165.

Wessels, W., Theocharopoulos, K. D., De Bruijn, H., \& Ünay, E. (2001). Myocricetodontinae and Megacricetodontini (Rodentia) from the lower Miocene of NW Anatolia. Lynx, 32, 371-388.

Zwick, A., \& Schleich, H. H. (1994). Quartäre Reptilienfunde von der Grabungsstelle Karain (S-Türkei). (Reptilia: Testudines, Squamata). Courier Forschungsinstitut Senckenberg, 173, 267-281. 